\title{
Опитувальник для визначення синдрому нічного переїдання (NEQ) - валідація та адаптація для української популяції
}

\section{Ф.В. Ланюш,} А.М. Урбанович

Львівський національний медичний університет ім. Данила Галицького

Резюме. Синдром нічного переїдання (СНП, night-eating syndrome) належить до «ншших специфічних порушень харчової поведінки». СНП характеризується наявністю нічного вживання їжі, безсонням, ранковою анорексією та розладами настрою і сну. Цей вид порушення харчової поведінки (ПХП) притаманний пацієнтам з ожирінням або надлишковою масою тіла та цукровим діабетом 2-го типу (ЦД2). Наявність СНП погіршує метаболічний контроль ЦД2 та ускладнює лікування цього захворювання. Наразі існує лише один метод, який дозволяє діагностувати цей синдром — опитувальник для визначення CHП (Night Eating Questionnaire, NEQ). На жаль, він не адаптований для використання в україномовній популяції. Мета: адаптувати та оцінити валідність української версії NEQ для застосування серед пацієнтів із ЦД2 та ожирінням або надлишковою масою тіла. Матеріал і методи. 105 осіб (37 чоловіків та 68 жінок, вік - 60,3 7,2 року, індекс маси тіла (IMT) -

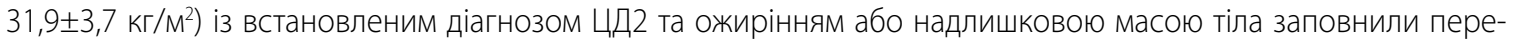
кладену версію NEQ. Внутрішню узгодженість опитувальника оцінювали за допомогою показника а-Кронбаха. Конвергентну валідність встановлювали за допомогою кореляції з «Опитувальником щодо розладів харчової поведінки» (Eating Disorder Examination Questionnaire, EDE-Q). Через 3 тижні 34 учасники пройшли ретестування. Результати. У 17 учасників (16,2\%) було встановлено діагноз СНП. Середній загальний бал опитувальника становив 17,3土5,1. Загальна надійність шкали (а-Кронбаха) для всього тесту становила 0,76, міжкласова кореляція - 0,81. Була встановлена 4-факторна структура опитувальника, яка відповідала оригінальній версії. Загальний бал NEQ корелював із результатом EDE-Q ( $r=0,56)$. Надійність ретесту була висока $(0,71)$. Показник IMT та HbA1 с статистично не відрізнявся в пацієнтів із та без СНП. Середній загальний бал опитувальника не корелював з IMT (p>0,05).

Висновки. Поширеність СНП серед пацієнтів із ЦД2 становить 16,2\%. Україномовна версія опитувальника $\in$ надійною та валідною для оцінки наявності СНП. Опитувальник може використовуватися в цієї категорії пацієнтів для встановлення діагнозу та вибору відповідного лікування. Необхідні подальші дослідження

() Ф.В. Ланюш, А.М. Урбанович 
Діагностика та лікування

ефективності NEQ серед пацієнтів із ЦД2 та нормальною масою тіла, а також в осіб з ожирінням або надлишковою масою тіла, але без цукрового діабету.

Ключові слова: цукровий діабет 2-го типу, ожиріння, надлишкова маса тіла, синдром нічного переїдання, опитувальник.

Згідно з класифікацією Американської психіатричної асоціації, СНП належить до категорії «Інших уточнених розладів харчової поведінки» [1]. До діагностичних критеріїв СНП належать: вживання $\geq 25 \%$ їжі від добового раціону після вечері або щонайменше 2 випадки на тиждень вживання їжі вночі; усвідомлення цих епізодів; та принаймні три з наступних ознак: ранкова анорексія; нестримне бажання їсти в проміжку між вечерею і сном або ж вночі; переконаність у тому, що вживання їжі допоможе заснути або повернутися до сну; безсоння та/або поганий настрій зранку [2].

Поширеність СНП у загальній популяції становить $1,1 \%$, а в тих, хто звертається до спеціалістів із метаболічної хірургії, - 2-20\% [3, 4]. Наявність СНП у пацієнтів із ЦД2 негативно впливає на метаболічний контроль та ускладнює ведення цих пацієнтів, зокрема в них вищі рівні глікованого гемоглобіну (HbA1c), артеріального тиску та IMT порівняно з особами, які не страждають на ПХП [5].

NEQ - це поки що єдиний затверджений інструмент діагностики цього ПХП. Цей опитувальник включає 14 запитань, які допомагають оцінити 4 різні компоненти СНП: вживання їжі вночі, вечірню гіперфагію, ранкову анорексію та розлади настрою і сну [2]. Опитувальник містить 2 «стоп»-критерії - запитання № 9 і № 12. Запитання № 13 стосується усвідомленості нічного вживання їжі та використовується для діагностики ПХП, пов'язаного зі сном, який є комбінацією парасомнії та нічного вживання їжі. Це запитання допомагає віддиференціювати вищезгадане ПХП від СНП та було виключене зі статистичного аналізу.

Вперше NEQ було опубліковано у 2008 році англійською мовою, а пізніше - перекладено та валідовано португальською ( $\alpha$-Кронбаха -

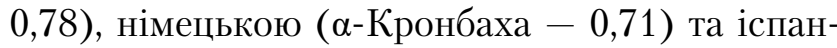
ською $(\alpha-$ Кронбаха - 0,79) мовами [6-9]. Проте української версії цього опитувальника не існує, що обмежує вчасне встановлення СНП та ранню інтервенцію для його оптимального лікування.
According to the classification of the American Psychiatric Association, NES belongs to «Other specified Feeding and Eating Disorder» [1]. Diagnostic criteria of this syndrome include: consumption of $\geq 25 \%$ of daily food intake after the evening meal or at least 2 nocturnal ingestions per week; awareness of these episodes; and at least three of the following signs: morning anorexia, a strong urge to eat between dinner and sleep or at night, insomnia, a belief that eating will help to initiate or return to sleep, and/or a worsening of mood in the evening [2].

The prevalence of NES in the general population is $1.1 \%$, and in those who turn to specialists in bariatric surgery - 2-20\% [3,4]. The presence of NES in patients with T2D has a negative impact on metabolic control and complicates the management of these patients, in particular they have higher levels of glycated hemoglobin (HbA1c), blood pressure and BMI compared to those who do not suffer from ED [5].

NEQ is currently the only approved instrument for NES assessment. It includes 14 items that help establish 4 different factors of NES: eating at night, evening hyperphagia, morning anorexia, and mood/sleep disorders [2]. The questionnaire contains 2 «stop» criteria questions № 9 and № 12. Question № 13 concerns awareness of nocturnal ingestion and is used to diagnose sleep-related eating disorder which is a combination of parasomnia and night eating. This question helps to differentiate it from NES and was exluded from the statistical analysis.

NEQ was first published in 2008 in English, and later translated and validated in Portuguese (Cronbach's alpha 0.78), German (Cronbach's alpha 0.71), and Spanish (Cronbach's alpha 0.79) [6-9]. However, the Ukrainian version of this questionnaire does not exist, which limits appropriate assessment of NES and early intervention for its optimal treatment.

The aim of our work was to adapt and validate the Ukrainian version of NEQ. Having 
Мета роботи - адаптація та оцінка валідності української версії NEQ. Враховуючи результати попередніх адаптацій опитувальника, ми очікували отримати прийнятну внутрішню узгодженість $(\alpha \geq 0,70)$, надійний результат ретесту $(r \geq 0,80)$ та 4-компонентну структуру.

\section{Матеріал і методи}

Дослідження включало наступні етапи:

1. Переклад попереднього варіанта опитувальника NEQ з англійської мови на українську професійним перекладачем.

2. Застосування перекладеної версії в пацієнтів із ЦД2 та ожирінням або надлишковою масою тіла.

3. Психометричний аналіз української версії NEQ (внутрішня узгодженість $-\alpha$-Кронбаха, стійкість до ретесту, дивергентна валідність з іншим опитувальником).

4. Стандартизація методики.

Процес перекладу складався із таких складових:

- переклад оригінальної версії опитувальника на українську мову професійним перекладачем;

- зворотний переклад опитувальника з української мови на англійську іншим перекладачем та порівняння $з$ оригінальною версією;

- використання української версії опитувальника в 105 пацієнтів із Цд2 та ретестування через 3 тижні в 34 із них.

Дослідження відбувалося згідно з Гельсінською декларацією Всесвітньої медичної асоціації «Етичні принципи медичних досліджень за участю людини в якості об'єкта дослідження». Кожен пацієнт підписав інформовану згоду. Дослідження було погоджено комісією з питань етики наукових досліджень, експериментальних розробок і наукових творів Львівського національного медичного університету ім. Данила Галицького (протокол № 10 від 16 грудня 2019 р.).

У дослідженні брало участь 105 пацієнтів (37 чоловіків та 68 жінок) із встановленим ЦД2 та ожирінням/надлишковою масою тіла. Середній вік становив 60,3 $\pm 7,2$ року, IMT $-31,9 \pm 3,7$ кг $/$ м $^{2}$. Критеріями виключення були: ЦД 1-го типу, вік $<40$ та $>80$ років, IMT $<24,9$ кг $/$ м $^{2}$, приймання психотропних препаратів протягом останніх 6 місяців. Порогове значення для діагностики СНП the results of previous adaptations of the questionnaire, we expected to obtain acceptable internal consistency $(\alpha \geq 0.70)$, a reliable testretest result $(r \geq 0.80)$ and to yield the fourfactor structure.

\section{Material and methods}

The study consisted of following stages:

1. Translation of the previous version of the NEQ questionnaire from English into Ukrainian by a professional translator.

2. Use of translated version in patients with T2D, obesity or overweight.

3. Psychometric analysis of the Ukrainian version of NEQ (internal consistency - Cronbach's alpha, resistance to retest, divergent validity with another questionnaire).

4. Standardization of methods.

The translation process consisted of the following stages:

- translation of the original version of the questionnaire into Ukrainian by a professional translator;

- reverse translation of the questionnaire from Ukrainian to English by another translator and comparison with the original version;

- use of the Ukrainian version of questionnaires in 105 patients with T2D and retest after 3 weeks in 34 participants.

The study was conducted according to the Helsinki Declaration of the World Medical Association «Ethical principles of medical research with human participation as an object of study». Each participant signed an informed consent. The study was approved by the Commission on Ethics of Research, Experimental Development and Scientific Works of Danylo Halytsky Lviv National Medical University (Protocol № 10, December 16, 2019).

The study included 105 patients (37 men and 68 women) with T2D, obesity or overweight. The mean age was $60.3 \pm 7.2$ years, body mass index $(\mathrm{BMI})-31.9 \pm 3.7 \mathrm{~kg} / \mathrm{m}^{2}$. Exclusion criteria were: type 1 diabetes, age $<40$ and $>80$ years, BMI $<24.9 \mathrm{~kg} / \mathrm{m}^{2}$, taking antidepressants for the last 6 months. The cut-off score for NES was $\geq 25$ points. A subgroup of patients $(n=34)$ was retested in 3 weeks. 
становило $\geq 25$ балів. Підгрупа пацієнтів (n=34) пройшла ретестування через 3 тижні.

EDE-Q містить 28 запитань та використовується для встановлення ПХП. Він складається 34 шкал: обмеження вживання їжі, психологічна стурбованість їжею, вагою та фігурою. Внутрішня узгодженість між шкалами коливається між $\alpha=0,85-0,93$ [10].

\section{Результати}

Після заповнення опитувальника в 17 пацієнтів (16,2\%) було діагностовано СНП. У табл. 1 наведено порівняння 2 груп пацієнтів: 1-а група $(\mathrm{n}=88)$ - особи з ЦД2 без СНП, 2-а група $(n=17)$ - особи з ЦД2 та СНП.

Загальний бал NEQ коливався від 1 до 38 балів $(\mathrm{M}=17,3 \pm 5,1) . \alpha$-Кронбаха для всього тесту становила 0,76. Також спостерігалася міжкласова кореляція між 4 блоками опитувальника $(0,81)$ та із загальним результатом. Психометричні показники української версії NEQ наведено в табл. 2.

Ретестування після 3 тижнів пройшли 34 пацієнти. У цю групу було включено осіб як із СНП, так і без даного ПХП. Надійність ретесту була висока $-0,71(\mathrm{p}<0,05)$.

\section{Обговорення}

Метою нашого дослідження було забезпечити український переклад та перевірити валідність «Опитувальника для визначення СНП» серед пацієнтів із ЦД2 та ожирінням або надлишковою масою тіла. Психометричні характеристики україномовного варіанта опитувальника
The EDE-Q has a 28-item instrument for the assessment of ED. It consists of four subscales: eating restraint, eating concern, weight concern, and shape concern. Internal consistencies of the subscales range between $\alpha=0.85-0.93$ [10].

\section{Results}

After completing the questionnaire, NES was diagnosed in 17 patients (16.2\%). The comparison of two study groups of patients is presented in the Table 1: 1st group $(n=88)-$ individuals with T2D without NES, 2nd group $(n=17)-$ individuals with T2D and NES.

Total NEQ score ranged from 1 to 38 points $(\mathrm{M}=17.3 \pm 5.1)$. Cronbach's $\alpha$ coefficient of the total scale was 0.76 . There was also an interclass correlation between the 4 blocks of the questionnaire (0.81) and with the overall result. The psychometric properties of the Ukrainian version of NEQ are presented in Table 2 .

34 patients were retested in 3 weeks. This group included both individuals with NES and without ED. The retest reliability was high $0.71(\mathrm{p}<0.05)$.

\section{Discussion}

The aim of our study was to provide a Ukrainian translation and to verify the validity of the NEQ in patients with $\mathrm{T} 2 \mathrm{D}$, obesity or overweight. Psychometric characteristics of the Ukrainian version generally corresponded to the original version [6]. No significant difference between BMI and HbA1c were found in the groups with and without NES.

Таблиця 1. Характеристика учасників дослідження

Table 1. Characteristics of study participants

\begin{tabular}{|c|c|c|}
\hline $\begin{array}{l}\text { Показники } \\
\text { Parameters }\end{array}$ & $\begin{array}{l}\text { 1-а група } \\
\text { Group } 1(n=88)\end{array}$ & $\begin{array}{l}\text { 2-а група } \\
\text { Group } 2(n=17)\end{array}$ \\
\hline $\begin{array}{l}\text { Bik (роки) } \\
\text { Age, years }\end{array}$ & $59,6 \pm 6,5$ & $60,9 \pm 7,8$ \\
\hline $\begin{array}{l}\text { Ріст (см) } \\
\text { Height, cm }\end{array}$ & $167,3 \pm 6,1$ & $165,1 \pm 6,4$ \\
\hline $\begin{array}{l}\text { Вага (кг) } \\
\text { Weight, kg }\end{array}$ & $87,4 \pm 7,8$ & $87,7 \pm 9,1$ \\
\hline $\begin{array}{l}\mathrm{IMT}\left(\mathrm{K} \Gamma / \mathrm{M}^{2}\right) \\
\mathrm{BMI}, \mathrm{kg} / \mathrm{m}^{2}\end{array}$ & $31,4 \pm 3,5$ & $32,3 \pm 3,8$ \\
\hline HbA1c (\%) & $10,2 \pm 1,8$ & $10,3 \pm 1,3$ \\
\hline $\begin{array}{l}\text { Загальний бал NEQ } \\
\text { Total NEQ score }\end{array}$ & $6,4 \pm 3,2$ & $28,2 \pm 3,3$ \\
\hline
\end{tabular}


Таблиця 2. Психометричні особливості української версії NEQ

Table 2. Psychometric properties of the Ukrainian version of NEQ

\begin{tabular}{|c|c|c|c|c|}
\hline \multirow[t]{2}{*}{$\begin{array}{l}\text { Запитання } \\
\text { Questions }\end{array}$} & \multicolumn{4}{|l|}{$\begin{array}{l}\text { Фактори } \\
\text { Factors }\end{array}$} \\
\hline & $\begin{array}{l}\text { Ранкова } \\
\text { анорексія } \\
\text { Morning } \\
\text { anorexia }\end{array}$ & $\begin{array}{l}\text { Вечірня } \\
\text { гіперфагія } \\
\text { Evening } \\
\text { hyperphagia }\end{array}$ & $\begin{array}{l}\text { Настрій / } \\
\text { Coн } \\
\text { Mood / } \\
\text { Sleep }\end{array}$ & $\begin{array}{l}\text { Нічне } \\
\text { вживання їжі } \\
\text { Nocturnal } \\
\text { ingestions }\end{array}$ \\
\hline $\begin{array}{l}\text { 1. Наскільки Ви зазвичай голодні зранку? } \\
\text { How hungry are you usually in the morning? }\end{array}$ & 0,82 & $-0,03$ & $-0,02$ & $-0,04$ \\
\hline $\begin{array}{l}\text { 2. Коли Ви зазвичай їсте вперше за день? } \\
\text { When do you usually eat for the first time? }\end{array}$ & 0,79 & 0,03 & 0,02 & 0,02 \\
\hline $\begin{array}{l}\text { 3. Чи маєте Ви нестримне бажання перекусити після вечері, але перед } \\
\text { тим, як іти спати? } \\
\text { Do you have cravings or urges to eat snacks after supper, but before } \\
\text { bedtime? }\end{array}$ & $-0,06$ & 0,83 & 0,03 & $-0,02$ \\
\hline $\begin{array}{l}\text { 4. Наскільки Ви контролюєте власне бажання перекусити після вечері, } \\
\text { але перед тим, як іти спати? } \\
\text { How much control do you have over your eating between supper and } \\
\text { bedtime? }\end{array}$ & $-0,02$ & 0,81 & 0,12 & 0,10 \\
\hline $\begin{array}{l}\text { 5. Скільки \% їжі від Вашого добового раціону Ви вживаєте після вечері? } \\
\text { How much of your daily food intake do you consume after suppertime? }\end{array}$ & 0,04 & 0,71 & $-0,12$ & 0,14 \\
\hline $\begin{array}{l}\text { 6. Чи почуваєтесь Ви засмучено або депресивно в останній час? } \\
\text { Are you currently feeling blue or down in the dumps? }\end{array}$ & $-0,03$ & 0,12 & 0,68 & 0,07 \\
\hline $\begin{array}{l}\text { 7. Коли Ви почуваєтесь сумно, Ваш настрій гірший ... } \\
\text { When you are feeling blue, is your mood lower in the: }\end{array}$ & $-0,13$ & $-0,32$ & 0,46 & $-0,02$ \\
\hline $\begin{array}{l}\text { 8. Як часто Ви маєте проблеми із засинанням? } \\
\text { How often do you have trouble getting to sleep? }\end{array}$ & 0,09 & 0,06 & 0,71 & 0,14 \\
\hline $\begin{array}{l}\text { 9. Як часто Ви піднімаєтеся вночі (за винятком того, щоб сходити } \\
\text { в туалет)? } \\
\text { How often do you get up at night (except to go to the toilet)? }\end{array}$ & 0,07 & $-0,04$ & 0,57 & 0,37 \\
\hline $\begin{array}{l}\text { 10. Чи маєте Ви непереборне бажання щось перекусити, коли } \\
\text { прокидаєтесь вночі? } \\
\text { Do you have cravings or urges to eat snacks when you wake up at night? }\end{array}$ & $-0,03$ & 0,11 & $-0,11$ & 0,86 \\
\hline $\begin{array}{l}\text { 11. Чи необхідно Вам щось з'їсти для того, щоб знову заснути? } \\
\text { Do you need to eat in order to get back to sleep when you awake at night? }\end{array}$ & $-0,02$ & $-0,08$ & 0,12 & 0,86 \\
\hline $\begin{array}{l}\text { 12. Коли Ви піднімаєтеся посеред ночі, як часто ви перекушуєте? } \\
\text { When you get up in the middle of the night, how often do you snack? }\end{array}$ & $-0,01$ & 0,20 & 0,17 & 0,91 \\
\hline $\begin{array}{l}\text { 13. Коли ви перекушуєте вночі, наскільки Ви це усвідомлюєте? } \\
\text { When you snack in the middle of the night, how aware are you of your } \\
\text { eating? }\end{array}$ & - & - & - & - \\
\hline $\begin{array}{l}\text { 14. Наскільки Ви контролюєте своє споживання їжі, коли прокидаєтесь } \\
\text { вночі? } \\
\text { How much control do you have over your eating while you are up at } \\
\text { night? }\end{array}$ & 0,07 & 0,03 & 0,12 & 0,70 \\
\hline
\end{tabular}

в загальному відповідали оригінальній версії [6]. Статистично значущої різниці між IMT та HbA1c у групах із та без СНП виявлено не було.

У нашому дослідженні загальний бал опитувальника не корелював з IMT, що було показано і в інших дослідженнях [11], хоча є дані про кореляцію СНП з ІМТ [9, 12]. Існує теорія, згідно 3 якою нічне вживання їжі може бути предиктором набору ваги в майбутньому.
In our study, the overall score of the questionnaire did not correlate with BMI, which was also shown in other similar studies [11], although there are data on the correlation of NES with BMI [9, 12]. There is a theory that night eating may be a predictor of weight gain in the future.

It was also found a four-factor questionnaire structure that corresponded to the original 
Також ми отримали 4-факторну структуру опитувальника, що відповідала первинному варіанту [6] і включала наступні шкали: вживання їжі вночі, вечірню гіперфагію, ранкову анорексію та розлади настрою і сну. Запитання № 13 («Коли ви перекушуєте вночі, наскільки Ви це усвідомлюєте?») не було включено в статистичний аналіз як обговорювалося вище.

Внутрішня узгодженість загальної шкали була прийнятною та відповідала версіям опитувальника іншими мовами $[6,8,9]$. Результати, отримані після ретесту, мали високу кореляцію iз первинними, що свідчить про ефективність цього опитувальника для постановки діагнозу СНП

Однак існує потреба в подальшому вивченні ПХП і СНП [13]. Деякі дослідження демонструють позитивну кореляцію між наявністю СНП та епізодами компульсивного чи емоційного переїдання [12]. Компульсивне неконтрольоване переїдання є основною характеристикою іншого ПХП - компульсивного переїдання (binge eating disorder). Доведено, що чим вищою $є$ імпульсивність, тим тяжчим є перебіг СНП [14]. Тому ця характеристика є властивою як компульсивному переїданню так і СНП, що потребує детальнішого вивчення [8].

\section{Висновки}

Психометричні характеристики адаптованої україномовної версії NEQ для визначення СНП схожі з оригінальною версією, що робить його придатним для скринінгу СНП серед пацієнтів із ЦД2 та ожирінням або надлишковою масою тіла при їх консультуванні. Використання NEQ може покращити контроль ЦД2 та ожиріння, оскільки він залишається єдиним інструментом для діагностики СНП. Необхідні подальші дослідження для встановлення зв'язку між різними видами ПХП у пацієнтів із ЦД2 та ожирінням або надлишковою масою тіла.

\section{Список використаної літератури / References}

1. Regier DA, Kuhl EA, Kupfer DJ. The DSM-5: Classification and criteria changes. World Psychiatry. 2013 Jun;12(2):92-8. doi: 10.1002/wps.20050.

2. Allison KC, Lundgren JD, O'Reardon JP, Geliebter A, Gluck ME, Vinai $P$, et al. Proposed diagnostic criteria for night eating syndrome. Int J Eat Disord. 2010 Apr;43(3):241-7. doi: 10.1002/ eat.20693. version [6] and included the following sections: nocturnal eating, evening hyperphagia, morning anorexia, and mood/sleep disorders. Question № 13 («When you snack at night, how much do you realize it?») was not included in statistical analysis as discussed in the introduction.

The internal consistency of the overall scale was acceptable and corresponded to the versions of the questionnaire in other languages $[6,8,9]$. The results obtained after the retest had a high correlation with the primary ones, which once again proves the reliability of this questionnaire for the NES diagnosis.

However, there is a need in further investigations of ED and NES [13]. Some studies demonstrate a positive correlation of NES with episodes of compulsive or emotional overeating [12]. Compulsive uncontrolled overeating is the core feature of another ED binge-eating disorder. It is proved that the higher the impulsivity, the more severe the course of NES. Therefore, this characteristic is inherent in both compulsive overeating and NES, which requires more detailed study [8].

\section{Conclusions}

The psychometric characteristics of the adapted Ukrainian version the determination of NEQ are similar to the original version, which makes it suitable for screening NES among patients with T2D, obesity or overweight at their consultation. The use of NEQ can improve control of T2D and obesity, as it remains the only tool for NES diagnosis. Further studies are needed to establish a link between different types of ED in patients with $\mathrm{T} 2 \mathrm{D}$, obesity or overweight.

3. de Zwaan M, Müller A, Allison KC, Brähler E, Hilbert A. Prevalence and correlates of night eating in the German general population. PLoS One. 2014 May 14;9(5): e97667. doi: 10.1371/journal. pone.0097667.

4. de Zwaan M, Marschollek M, Allison KC. The Night Eating Syndrome (NES) in bariatric surgery patients. Eur Eat Disord Rev. 2015 Nov;23(6):426-34. doi: 10.1002/erv.2405.

5. Meneghini LF, Spadola J, Florez H. Prevalence and associations of binge eating disorder in a multiethnic population with type 2 diabetes. Diabetes Care. 2006 Dec;29(12):2760. doi: 10.2337/ dc06-1364. 
6. Allison KC, Lundgren JD, O'Reardon JP, Martino NS, Sarwer DB, Wadden TA, et al. The Night Eating Questionnaire (NEQ): psychometric properties of a measure of severity of the Night Eating Syndrome. Eat Behav. 2008 Jan;9(1):62-72. doi: 10.1016/j. eatbeh.2007.03.007.

7. da Silva FGC, Pinto TF, de Souza EA, de Bruin VMS, de Bruin PFC. Adaptation of the night eating questionnaire for Brazilian adolescents. Sleep Sci. 2020 Apr-Jun;13(2):103-6. doi: 10.5935/1984-0063.20200002.

8. Meule A, Allison KC, Platte P. A German version of the Night Eating Questionnaire (NEQ): psychometric properties and correlates in a student sample. Eat Behav. 2014 Dec;15(4):523-7. doi: 10.1016/j.eatbeh.2014.07.002.

9. Moizé V, Gluck ME, Torres F, Andreu A, Vidal J, Allison K Transcultural adaptation of the Night Eating Questionnaire (NEQ) for its use in the Spanish population. Eat Behav 2012 Aug;13(3):260-3. doi: 10.1016/j.eatbeh.2012.02.005

10. Hilbert A, Tuschen-Caffier B, Karwautz A, Niederhofer $H$ Munsch S. Eating disorder examination-questionnaire. Diagnostica. 2007 Jul;53(3):144-54. doi: 10.1026/0012-1924.53.3.144.

11. Runfola CD, Allison KC, Hardy KK, Lock J, Peebles R. Prevalence and clinical significance of night eating syndrome in university students. J Adolesc Health. 2014 Jul;55(1):41-8. doi: 10.1016/j. jadohealth.2013.11.012.

12. Harb A, Levandovski R, Oliveira C, Caumo W, Allison KC, Stunkard A, Hidalgo MP. Night eating patterns and chronotypes: a correlation with binge eating behaviors. Psychiatry Res. 2012 Dec 30;200(2-3):489-93. doi: 10.1016/j.psychres.2012.07.004.

13. Ланюш ФВ, Урбанович АМ. Порушення харчової поведінки у хворих на цукровий діабет 2 типу. Проблеми ендокринної патології. 2020 вер; 73(3):119-25 (Laniush FV, Urbanovych AM. Eating disorders in patients with type 2 diabetes. Problems of Endocrine Pathology. 2021;73(3):119-25. Ukrainian). doi: 10.21856/j-PEP.2020.3.15.

14. Meule A. Impulsivity and overeating: a closer look at the subscales of the Barratt Impulsiveness Scale. Front Psychol. 2013 Apr 10;4:177. doi: 10.3389/fpsyg.2013.00177.

\section{Night-Eating Questionnaire (NEO) - validation and adaptation for the Ukrainian population}

\section{F.V. Laniush, A.M. Urbanovych \\ Danylo Halytsky Lviv National Medical University}

\begin{abstract}
Night-eating syndrome (NES) belongs to «Other specified Feeding and Eating Disorder». NES is characterized by nocturnal food intake, insomnia, morning anorexia and depressed mood. This eating disorder (ED) is typical for patients with type 2 diabetes (T2D), obesity or overweight. NES worsens the metabolic contro of T2D and complicates its management. Currently, there is only one assessment instrument which can help to diagnose this syndrome - night eating questionnaire (NEQ). Unfortunately, it is not yet adapted to use in the Ukrainian population. Aim: Evaluation of the validity of NEQ adaptations of the Ukrainian version for its use in patients with T2D, obesity or overweight. Material and methods. 105 individuals (37 men and 68 women, age $-60.3 \pm 7.2$ years, body mass index (BMI) $-31.9 \pm 3.7 \mathrm{~kg} / \mathrm{m}^{2}$ ) with $\mathrm{T} 2 \mathrm{D}$, obesity or overweight completed the translated version of NEQ. The internal consistency of the questionnaire was assessed using the Cronbach's alpha coefficient. Convergent validity was assessed by correlation with the Eating Disorder Examination Questionnaire (EDE-Q). Testretest was performed in three weeks by 34 participants. Results.
\end{abstract}

NES was diagnosed in 17 participants (16.2\%). Mean NEQ total score was 17.3 \pm 5.1 . Cronbach's alpha coefficient for the total score was 0.76 , interclass correlation - 0.81. A four-factor questionnaire structure was found similar to the original version. The total NEQ score correlated with the EDE-Q result $(r=0.56)$. The reliability of the retest was high (0.71). BMI and HbA1c did not statistically differ in patients with and without NES. The mean NEQ total score did not correlate with BMI ( $p>0.05)$. Conclusions. The prevalence of NES in patients with $\mathrm{T} 2 \mathrm{D}$ is $16.2 \%$. The Ukrainian version of the questionnaire is reliable and valid for assessing NES. NEQ can be used in this category of patients for making the diagnosis and choosing an appropriate treatment. Further studies on normal weight diabetic and non-diabetic obese and overweight individuals are needed. Further studies of the NEQ efficacy are needed in patients with T2D and normal body weight, as well as in obese or overweight people but without diabetes.

Keywords: type 2 diabetes, obesity, overweight, night eating syndrome, questionnaire.

\section{Опросник для определения синдрома ночного переедания (NEQ) - валидация и адаптация для украинской популяции}

\section{Ф.В. Ланюш, А.М. Урбанович}

Львовский национальный медицинский университет им. Данила Галицкого

Резюме. Синдром ночного переедания (СНП, night-eating syndrome) принадлежит к «Другим специфическим пищевым расстройствам». СНП характеризуется ночным приемам пищи, бессоницей, утренней анорексией и депрессивным настроением. Это расстройство пищевого поведения (РПП) типичное для пациентов с ожирением или избыточной массой тела и сахарным диабетом 2-го типа (СД2). Наличие СНП ухудшает метаболический контроль СД2 и затрудняет лечение данного заболевания. Сейчас существует только один метод, который позволяет диагностировать данный синдром - опросник для определения СНП (Night Eating Questionnaire, NEQ). К сожалению, он не адаптирован для применения в украиноязычной популяции Цель: адаптировать и оценить валидность украинской версии опросника NEQ для применения у пациентов с СД2 и ожирением или избыточной массой тела. Материал и методы. 105 человек (37 мужчин и 68 женщин, возраст - 60,3土7,2 года, индекс

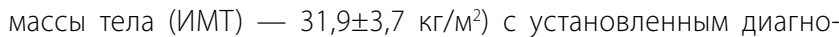
зом СД2 и ожирением или избыточной массой тела заполнили переведенную версию NEQ. Внутреннюю согласованность опросника оценивали с помощью показателя а-Кронбаха. Конвергентную валидность устанавливали с помощью корреляции с «Опросником изучения пищевых расстройств» (Eating Disorder Examination Questionnaire, EDE-Q). Через 3 недели 34 участника прошли ретестирования. Результаты. У 17 участников (16,2\%) 
Діагностика та лікування

был установлен диагноз СНП. Средний общий балл опросника

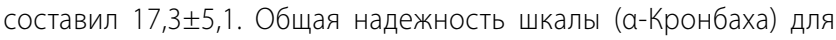
всего теста составляла 0,76, межклассовая корреляция - 0,81. Была установлена 4-факторная структура опросника, которая соответствовала оригинальной версии. Общий балл NEQ коррелировал с результатом EDE-Q $(r=0,56)$. Надежность ретеста была высокая $(0,71)$. Показатель ИМТ и НbA1с статистически не отличались у пациентов с и без СНП. Средний общий балл опросника не коррелировал с ИМТ (р>0,05). Выводы. Распространенность СНП среди пациентов с СД2 составляет 16,2\%. Украиноязычная версия опросника является надежным и валидным инструментом для определения наличия СНП. Опросник может использоваться в данной категории пациентов для постановки диагноза и выбора подходящей терапии. Необходимы последующие изучения эффективности NEQ у лиц с ожирением или избыточной массой тела, но без сахарного диабета.

Ключевые слова: сахарный диабет 2-го типа, ожирение, избыточная масса тела, синдром ночного переедания, опросник.

Для цитування: Ланюш ФВ, Урбанович АМ. Опитувальник для визначення синдрому нічного переїдання (NEQ) — валідація та адаптація для української популяції. Ендокринологія. 2021;26(3):311318. DOI: 10.31793/1680-1466.2021.26-3.311.

Адреса для листування: Ланюш Федір Вікторович, alinaur@ dr.com; Львівський національний медичний університет ім. Данила Галицького, вул. Пекарська, 69, Львів, 79010, Україна.

Відомості про авторів: Ланюш Федір Вікторович, аспірант кафедри ендокринології Львівського національного медичного університету ім. Данила Галицького, ORCID: 0000-0003-08912082; Урбанович Аліна Мечиславівна, д-р мед. наук, проф., завідувачка кафедри ендокринології Львівського національного медичного університету ім. Данила Галицького, ORCID: 00000003-3676-7345.

Особистий внесок: Ф.В. Ланюш - написання фрагменту статті, аналіз літературних джерел, статистичний аналіз даних і відбір пацієнтів для дослідження; А.М. Урбанович - розробка концепції статті, написання фрагмента статті, відбір пацієнтів для дослідження і редагування статті.

Фінансування: власні кошти авторів.

Декларація з етики: автори задекларували відсутність конфлікту інтересів і фінансових зобов'язань.

Стаття: надійшла до редакції 28.07 .2021 р.; перероблена 21.09.2021 р.; прийнята до друку 01.10.2021р.; надрукована 20.10.2021 p.
For citation: Laniush FV, Urbanovych AM. Night-Eating Questionnaire (NEQ) — validation and adaptation for the Ukrainian population. Endokrynologia. 2021;26(3):311-318. DOl: 10.31793/1680-1466.2021.26-3.311.

Correspondence address: Fedir Laniush, alinaur@dr.com; Danylo Halytsky Lviv National Medical University, Pekarska Street, 69, Lviv, 79010, Ukraine.

Information about the authors: Laniush Fedir Viktorovych, PhDstudent at the Department of Endocrinology, Danylo Halytsky Lviv National Medical University, ORCID: 0000-0003-0891-2082; Urbanovych Alina Mechyslavivna, Dr. Sci. (Medicine), Prof., Head of the Department of Endocrinology, Danylo Halytsky Lviv National Medical University, ORCID: 0000-0003-3676-7345.

Personal contribution: Laniush F.V. - writing a fragment of the article, analysis of literature, statistical analysis of data and selection of patients for research; Urbanovych A.M. - development of the article concept, writing a fragment of the article, selection of patients for research and editing the article.

Funding: own funds of authors.

Declaration of ethics: the authors declared the absence of a conflict of interest and financial obligation.

Article: received 28 July 2021; revised 21 September 2021; accepted 01 October 2021; published 20 October 2021.

Для цитирования: Ланюш ФВ, Урбанович АМ. Опросник для определения синдрома ночного переедания (NEQ) - валидация и адаптация для украинской популяции. Эндокринология. 2021;26(3):311-318. DOI: 10.31793/1680-1466.2021.26-3.311.

Адрес для переписки: Ланюш Федор Викторович, alinaur@ dr.com; Львовский национальный медицинский университет им. Данила Галицкого, ул. Пекарская, 69, Львов, 79010, Украина.

Сведения об авторах: Ланюш Федор Викторович, аспирант кафедры эндокринологии Львовского национального медицинского университета им. Данила Галицкого, ORCID: 0000-0003-08912082; Урбанович Алина Мечиславовна, д-р мед. наук, профессор, заведующая кафедрой эндокринологии Львовского национального медицинского университета им. Данила Галицкого, ORCID: 0000-0003-3676-7345

Личный вклад: Ланюш Ф.В. - написание фрагмента статьи, анализ литературных источников, статистический анализ данных и отбор пациентов для исследования; Урбанович А.М. - разработка концепции статьи, написанные фрагмента статьи, отбор пациентов для исследования и редактирование статьи.

Финансирование: личные средства авторов.

Декларация по этике: авторы задекларировали отсутствие конфликта интересов и финансовых обязательств.

Статья: поступила в редакцию 28.07.2021 г.; переработана 21.09.2021 г.; принята в печать 01.10.2021 г.; напечатана 20.10.2021 г. 